\title{
Evaluation of the anti-diabetic effects of epicatechin and/or gallic acid in STZ/NA- induced diabetic Wister rats
}

\author{
Gehan M. Ibrahim ${ }^{1}$, Osama M. Ahmed ${ }^{2}$, Nasser H. Abbas ${ }^{1}$, Mahmoud M. El Fateh ${ }^{1}$
}

1, Department of Molecular Biology, Genetic Engineering and Biotechnology Research institute (GEBRI), Sadat City University.

2, Physiology Division, Zoology Department, Faculty of Science, Beni-Suef University, Beni-Suef, Egypt

Corresponding author:

Email:

\begin{abstract}
:
Diabetes, is a group of metabolic diseases in which there are high blood glucose levels over a prolonged period. If left untreated, diabetes can cause many complications. The present study was aimed to investigate in vivo, effects of treatment with epicatechin and/or gallic acid efficacy on glycemic state, serum insulin, C-peptide levels, lipid profile and heart function in NA/STZ-induced diabetic rats. The rats were divided into five groups that are normal control, diabetic control, diabetic group treated with epicatechin, diabetic group treated with gallic acid and diabetic group treated with the mixture of epicatechin and gallic acid. The study suggested that treatment of diabetic rats with epicatechin and/or gallic acid markedly improved the impaired oral glucose tolerance, serum insulin level, mRNA expression of GLUT4, insulin resistin, and serum lipid profile and serum enzyme activities related to heart function. Also, the treatment of diabetic group epicatechin and gallic acid together was the most effective in improving the previous indicies.
\end{abstract}

Keywords: Diabetes mellitus; epichatchin; gallic acid; insulin resistant; glucose transporter type 4 and STZ/NA diabetic rats.

\section{INTRODUCTION}

Diabetes mellitus (DM) is a group of metabolic diseases characterized by hyperglycemia resulting from insulin deficiency and / or insulin resistance. The chronic hyperglycemia of diabetes is associated with long-term damage, dysfunction, and failure of various organs, especially the eyes, kidneys, nerves, heart, and blood vessels (American Diabetes Association $\{A D A\}, 2014)$. For these reasons, it is essential to discover not only a cure for

This condition, ancient Egyptian physicians were advocating the use of wheat grains, fruit, and sweet beer (Korczowski et al., 1985). diabetes but also for its complications to improve the quality of life and decrease the rate of mortality (Forbes and Cooper, 2013).

Ebers Papyrus, which was written around $1500 \mathrm{BC}$, excavated in $1862 \mathrm{AD}$ from an ancient grave in Thebes, Egypt, and published by Egyptologist Georg Ebers in 1874, describes, among various other ailments and their remedies, a condition of "too great emptying of the urine" - perhaps, the reference to diabetes mellitus. For the treatment of

Physicians in India at around the same time developed what can be described as the first clinical test for diabetes. They observed that the urine from people with diabetes attracted ants and flies. They named the condition 
"madhumeha" or "honey urine." Indian physicians also noted that patients with "madhumeha" suffered from extreme thirst and foul breath (probably, because of ketosis) (Roy et al., 2011).

Although the polyuria associated with diabetes was well recognized, ancient clinicians could not distinguish between the polyuria due to what we now call diabetes mellitus from the polyuria due to other conditions.3 Around 230 $\mathrm{BC}$, Apollonius of Memphis for the first time used the term "diabetes," which in Greek means "to pass through" (dia - through, betes - to go). $\mathrm{He}$ and his contemporaries considered diabetes a disease of the kidneys and recommended, among other ineffective treatments, such measures as bloodletting and dehydration. The first complete clinical description of diabetes appears to have been made by Aulus Cornelius Celsus (30 BC-50 AD). Often called "Cicero medicorum" for his elegant Latin, Celsus included the description of diabetes in his monumental eight-volume work entitled De medicina (Maiti et al., 2004)

Aretaeus of Cappadocia, a Greek physician who practiced in Rome and Alexandriain Anno Domini (AD), was the first to distinguish

Plants have always been an exemplary source of drugs and many of the currently available drugs have been derived directly or indirectly from them. The ethnobotanical information reports about 800 plants that may possess antidiabetic potential. The field of herbal medicines research has been gaining significant importance in the last few decades and the demand to use natural products in the treatment of diabetes is increasing worldwide (Bnouham, 2006). Among the known natural bioactive components and phytochemicals, recently phenolic compounds are very popular because of their safety and efficacy (Hanhineva et al., 2010). between what we now call diabetes mellitus and diabetes insipidus (Wu et al., 2015).

Type 2 diabetes is a disease in which the body loses its ability to produce and use insulin, a hormone made by the pancreas. After the body breaks down sugar and starch from food, insulin delivers the glucose to cells that absorb it and use it for energy. Insulin also helps to eliminate extra glucose from the blood (Godinho et al., 2015).

Wistar rats consider as a good model for type II DM that displays many of the characteristics of the human disease including hyperphagia, hyperglycemia, insulin resistant and progressive obesity (Leiter and Reifsnyder, 2004).

Traditional herbal medicine is used for treatment of diabetes in developing countries where the cost of conventional medicines is a burden to the population (Maiti et al., 2004). Despite the introduction of hypoglycemic agents from natural and synthetic sources, diabetes and its secondary complications continue to be a major medical problem. One of the great advantages of medicinal plants is that these are readily available and have very low side effects (Atanasov et al., 2015).

Catechins and epicatechins are phytochemical compounds present in high concentrations in a variety of plant-based foods and beverages. According to their structure, these compounds are classified as flavanols and include the following compounds: catechin, epicatechin, epigallocatechin, epicatechingallate, and epigallo catechingallate. High amount of catechin can be found in red wine, broad beans, black grapes, apricots and strawberries. epicatechin are high in apples, blackberries, broad beans, cherries, black grapes, black and green tea, pears, raspberries, and cocoa/chocolate (Raederstoff et al., 2003; Williamson and Manach, 2005). There are 
beneficial effects that the consumption of foods containing high level of catechins and epicatechins has been associated with a variety of beneficial biological effects; increased plasma antioxidant activity, brachial artery dilation, fat oxidation, resistance of LDL to oxidation and promotion of gut health (Khan et al., 2014).

GA is a component of naturally occurring esters of gallic acid that belong to the larger group of plant polyphenols known as gallotannins which are present in legumes, fruits, vegetables and derivative products (Manach et al., 2005). Gallotannins, especially green tea is an important source of GA and contains up to $4.5 \mathrm{~g} / \mathrm{kg}$ of fresh weight

\section{MATERIALS AND METHODS}

\section{Experimental Animals:}

Adult Wistar rats weighing $120 \pm 20 \mathrm{~g}$ were used in the present study. They were kindly supplied from Helwan Station for Experimental Animals, Egyption organization for Biological products and Vaccines (VACSERA), Helwan, Egypt. They were kept under observation for two weeks before the onset of the experiment to exclude any intercurrent infection. The chosen animals were housed in clean polypropylene cages (47 x $34 \mathrm{x}$ $20 \mathrm{~cm}$ ), lined with husk (replaced every $24 \mathrm{~h}$ ), and were fed with standard pellet diet and water. The animals were acclimatized to laboratory condition (temperature $25 \pm 5^{\circ} \mathrm{C}$ ), humidity $(55 \pm 5 \%)$ and normal 12 hours' dark/light cycle. The animal procedures were conducted according to the principles and guidelines of the Canadian committee for care and use of animals the (Canadian council on animal care $\{$ CCAC $\}, 1993$ ).

\section{Induction of diabetes mellitus:}

Diabetes mellitus type 2 was experimently induced in overnight fasted rats by single intraperitoneal injection (i.p) of 120 $\mathrm{mg} / \mathrm{kg}$ b.w. nicotinamide (NA) dissolved in
(Reckziegel et al., 2011). GA were reported to have several biological activities including anticancer, antioxidant, antibacterial, antiviral, antitumor, anti-inflammatory (Liao et al., 2012) and cardio-protective effects (Mansouri et al., 2013). In recent years, gallotannins have been searched for their antihyperglycemic, lipid lowering, and antioxidant activities (Islam et al., 2016).

Currently, there is much interest in the usefulness of plants. Therefore, this study was designed to assess the anti-hyperglycemic and anti-hyperlipidemic and cardioprotective effects and to suggest the probable mechanisms of action of epicatechin and/or gallic acid in STZ/NA induced diabetic rats.

$\mathrm{NaCl}$ solution (0.9\%) 15 minutes before intraperitoneal injection of $50 \mathrm{mg} / \mathrm{kg} \mathrm{b.w}$ streptozotocin (Sigma Chemical Company) dissolved in citrate buffer ( $\mathrm{pH} 4.5$ ) (Masiello et al., 1998). Ten days after streptozotocin injection, rats were deprived of food overnight (8-10 hours), blood samples were taken from a tail lateral vein after 2 hours of oral glucose loading (3 $\mathrm{g} / \mathrm{kg} \quad$ b.w), and serum glucose concentration was measured by Glucometer (Accu Chek-Germany), Rats with a 2-hour serum glucose level ranging from 180 to 300 $\mathrm{mg} / \mathrm{dl}$ were considered mildly diabetic and included in the experiment.

\section{Animal Grouping and experimental design:}

In the present study, a total of 30 rats were used. The rats were divided into five groups each group comprising of six rats $(n=6)$ designated as follows:

Normal control: The rats within this were daily administrated an equivalent volume of vehicle by oral gavage.

Diabetic control: The rats in this group were daily administrated an equivalent volume of vehicle by oral gavage.

Diabetic treated with epicatechin: The rats included in this group were diabetic rats that were treated with epicatechin by oral gavage at 
dose level of $10 \mathrm{mg} / \mathrm{kg}$ b.wt./day for 4 week (Pannala VR, 2010).

Diabetic treated with gallic acid: The rats included in this group were diabetic rats that were treated with gallic acid by oral gavage at dose level of $10 \mathrm{mg} / \mathrm{kg}$ b.wt./day for 4 week (Latha and Daisy, 2011).

Diabetic treated with epicatechin and gallic acid: The rats included in this group were diabetic rats that were treated with epicatechin of dose $10 \mathrm{mg} / \mathrm{kg}$ b.wt./day and gallic acid 10 $\mathrm{mg} / \mathrm{kg}$ b.wt./day by oral gavage for 4 week.

All treatments were dissolved in $0.5 \%$ carboxymethyl cellulose (CMC) and given daily for 4 weeks by oral gavage. The body weight of experimental groups was recorded at the beginning (initial) and at the end (final) of the treatment period.

\section{Blood and tissue collection:}

A day before sacrifice, the experimental animals in all groups were deprived of food overnight (8-10 hours). Blood samples were obtained from lateral tail vein under diethyl ether anesthesia at fasting state and at one hours, two hours and three hours of oral glucose loading ( $3 \mathrm{~g} / \mathrm{kg}$ b.wt). After the last treatment, rats were fasted overnight and sacrificed and blood was collected from jagular vein the head was dislocated from the rest of the body by decapitation. Serum was obtained after centrifugation at 3000 r.p.m for 30 minutes. The clear non-hemolysed supernatant serum were quickly removed, divided into three portions for each individual animal, and kept at $-20^{\circ} \mathrm{C}$ for estimation of blood glucose and plasma insulin and other tests.

\section{Determination of oral glucose tolerance test} (OGTT):

On the day before sacrifice, the OGTT was performed in normal control, diabetic control, diabetic groups treated with epicatechin, gallic acid and their mixture. Blood samples were obtained from lateral tail vein of rats deprived of food overnight (8-10 hours) successive blood samples were then taken at 0 ,
60, 120, and 180 minutes following administration of $(3 \mathrm{~g} / \mathrm{kg}$ b.wt $)$ through oral gavage. Blood samples were left to coagulate and centrifuged. Then, clear non-hemolyzed serum was obtained for determination of glucose concentration by Glucometer, AccuChek, Germany.

Determination of insulin and C-peptide levels:

Serum insulin and C-Peptide levels were determined according to the method of Anthony Campbell, Chemiluminescence (Anthony, 2017) Using reagent kits purchased from TradeMed Company (China).

Homeostatic model assessment (HOMA):

A method used to quantify insulin resistance (HOMA-IR), insulin sensitivity (HOMA-IS) and beta-cell function (HOMA- $\beta$ cell function). Were calculated according to (Park et al., 2009).

HOMA-IR. This value is calculated according to the following equation:

HOMA-IR =

Fasting insulin $\mathrm{x}$ fasting glucose (mg/dl)

405

HOMA-IS. This value is calculated according to the following equation: HOMA-IS = 10000

Fasting insulin $\mathrm{x}$ fasting glucose $(\mathrm{mg} / \mathrm{dl})$

HOMA- $\beta$ cell function. This value is calculated according to the following equation:

HOMA- $\boldsymbol{\beta}$ cell function $=$

$20 \mathrm{x}$ fasting insulin $(\mu \mathrm{IU} / \mathrm{ml})$

Fasting glucose $(\mathrm{mg} / \mathrm{dl})-3.5$ 


\section{Detection of mRNA expression of resistin and GLUT4:}

\section{RNA isolation and RT-PCR analysis}

Total RNA was isolated from Visceral adipose tissue according to the method of chomzynski and sacchi (1987), using thermo scientific Gene Jet RNA purification kit obtained from thermos fisher scientific Inc., Rochester, New York, USA. Reverse transcription (RT) of RNA into cDNA and the PCR amplification in the presence of specific primers of resistin and GLUT4 was performed using therom scientific Verso 1-Step RT-PCR Reddy Mix Kit (Thermos fisher scientific Inc., Rochester, New York, USA) and thermal cycler Techen 312 (Fisher scientific, Leicester. LE11
5RG). The sense and anti-sense specific primers of resistin and GLUT4 were obtained from Biosearch technologies, south McDowell Blud, Petaluma, CA, USA.

The RT-PCR products were loaded and electrophoresed at 90 Volts on $1.5 \%$ agarose gel stained with ehidium bromide in $1 \mathrm{X}$ Tris Borate EDTA buffer (TBE) $\mathrm{pH}$ 8.3-8.5). The bands on the agarose gel were viewed by UV transilluminator in a dark chamber and photographed by a camera using Gel Documentation System obtained from Raya GelDocu Advanced Program accessed from Raya for the Scientific Services, Giza, Egypt. The mRNA levels of resistin and GLUT4 were normalized to $\beta$-actin.

\begin{tabular}{|l|l|l|l|}
\hline Gene & \multicolumn{1}{|c|}{ Forward primer sequence } & \multicolumn{1}{c|}{ Reverse primer sequence } & \multicolumn{1}{c|}{ Ref. } \\
\hline $\begin{array}{l}\text { B-actin } \\
\text { (housekeeping } \\
\text { gene) }\end{array}$ & 5'TCACCCTGAAGTACCCCATGGAG3' & 5'TTGGCCTTGGGGTTCAGGGGG3' & $\begin{array}{l}\text { Shaker and } \\
\text { Sourour }\end{array}$ \\
GLUT4 & 5'GGACCGCGAATAGAAGAAAGAC3' & 5'CAACTTCATCATCGGCATGG3', & Bing et al., \\
Resisten & 5'AGTCCACAGAGAGGCACCTG' & 5'GCGCAGTCTTAGGCTACTGG3' & Tokushi et al., \\
\hline
\end{tabular}

Determination of lipid profile:

Serum total cholesterol, triglycerides, hight density lipoprottien and low density lipoprotien concentrations was determined according to (Greenan et al., 1995). Using reagent kits purchased from Human Diagnostics (Germany).

\section{Statistical analysis:}

The data were analyzed using paired samples test of statistical package for social scinces (SPSS, program, version 18 for windows) (SPSS Inc. Chicago, IL, USA) was used for analysis of the data. Paired-Sample-T
Determination of Heart function indicators:

The activities of serum aspartate aminotransferase (AST), Lactate dehydrogenase (LDH) and creatin kinase $-\mathrm{MB}$ were determined according to the method of (Fiolet et al., 1977; Gella et al., 1985 and Holmes et al., 2009).

test is used to compare the results of various groups with each other's. $\mathrm{P}$ value $<0.05$ was considered statistically significant. Data are expressed as mean \pm SEM. 


\section{RESULTS}

Effect of epicatechin and/or gallic acid on glucose tolerance

As illustrated in figure 1; the glucose tolerance curves of normal, diabetic control and diabetic treated rats reached their peaks at 1 hour after glucose loading, then decrease gradually as the time extended to 3 hours. The OGTT curve of diabetic rats exhibited an enormous elevation as compared with that of

normal ones. The serum glucose level of diabetic rats was highly significantly increased at all points $(\mathrm{P}<0.05)$ at all points of OGTT as compared with their corresponding normal values. The oral administration of epicatechin and/or gallic acid for 4 weeks produce a great variation.

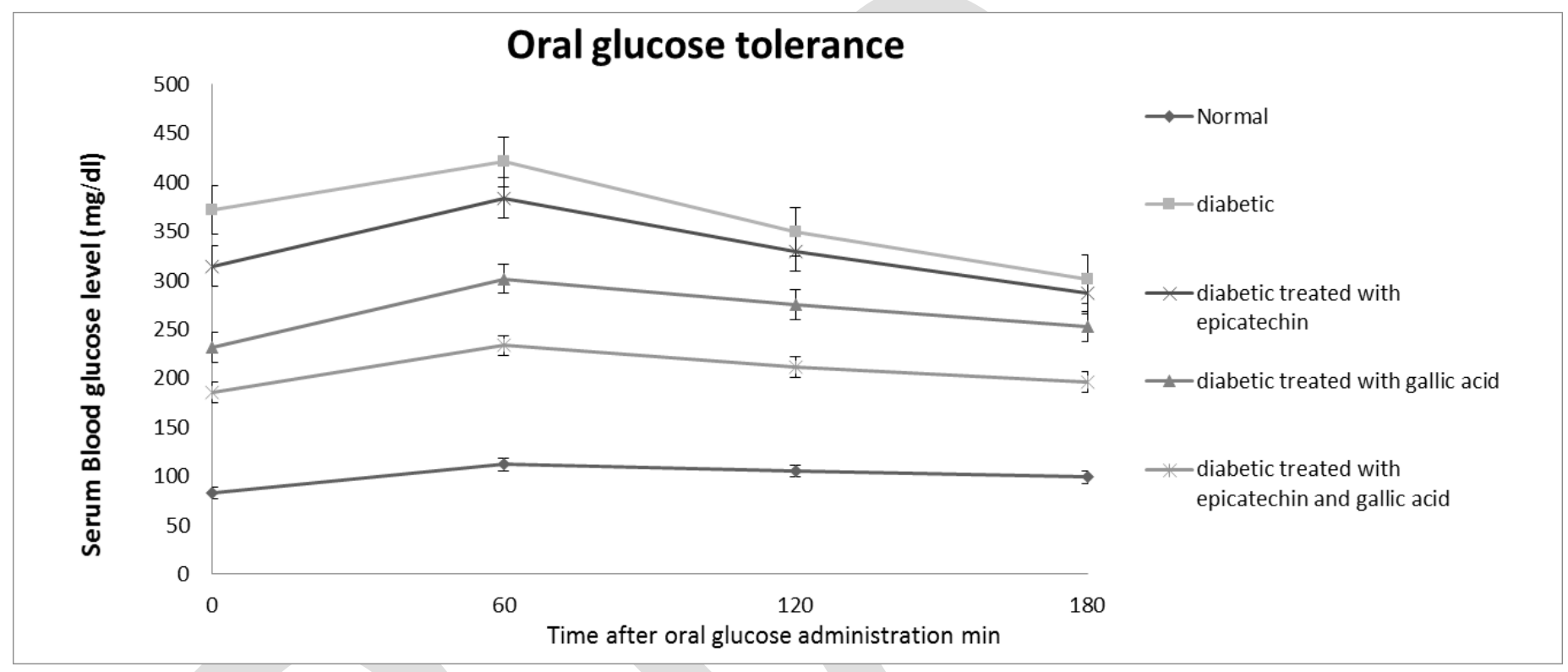

Figure 1. Effect of epicatechin and/or gallic acid on OGTT in STZ/NA induced diabetic rats.

Effect of epicatechin and/or gallic acid on insulin and $\mathrm{C}$-peptide levels

Also founded that treatment of diabetic groups with epicatechin or gallic acid leads to increase in insulin level but the treatment with both epicatechin and gallic acid in combination produced significant increase in insulin and $\mathrm{C}$ peptide level ( $\mathrm{p}$ value $<0.05$ ) as in table 1.

Table 1: effect of epicatchin and/or gallic acid on serum insulin and C-peptide in NA/STZ induced diabetic rats.

\begin{tabular}{|c|c|c|}
\hline Groups & $\begin{array}{l}\text { Insulin } \\
\text { (mIU/mL) }\end{array}$ & $\begin{array}{l}\text { C Peptide } \\
\text { (ng/mL) }\end{array}$ \\
\hline Normal & $9.36 \pm 0.53$ & $1.87 \pm 0.15$ \\
\hline Diabetic control & $2.4 \pm 0.34^{a}$ & $0.45 \pm 0.05^{a}$ \\
\hline Diabetic rats treated with epicatechin & $4.53 \pm 0.35^{b}$ & $0.58 \pm 0.04^{b}$ \\
\hline Diabetic rats treated with gallic acid & $4.16 \pm 0.43^{b}$ & $0.61 \pm 0.06^{b}$ \\
\hline
\end{tabular}




\begin{tabular}{|c|c|c|}
\hline Parameter & \multirow[b]{2}{*}{$\begin{array}{c}\text { Resisting mRNA/B- } \\
6.45 \pm 0.45 \\
\operatorname{actin}(\%)\end{array}$} & \multirow[b]{2}{*}{ 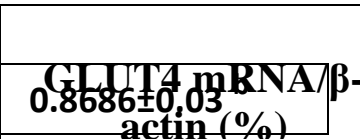 } \\
\hline Diabetic rats treated with epicatechin GFfuggallic acid & & \\
\hline
\end{tabular}

\begin{tabular}{|c|c|c|c|}
\hline $\begin{array}{ll}\text { Groups } & \text { Parameters } \\
\end{array}$ & $\begin{array}{l}\text { HOMA- } \beta \text { cell } \\
\text { function }\end{array}$ & HOMA IS & HOMA IR \\
\hline Normal & $2.18 \pm 0.32$ & $1.40 \pm 0.07$ & $1.70 \pm 0.08$ \\
\hline Diabetic control & $0.18 \pm 0.04^{a}$ & $0.71 \pm 0.11^{\mathrm{a}}$ & $2.68 \pm 0.17^{\mathrm{a}}$ \\
\hline Diabetic rats treated with epicatechin & $0.35 \pm 0.05^{b}$ & $0.96 \pm 0.01^{b}$ & $2.30 \pm 0.04^{b}$ \\
\hline Diabetic rats treated with gallic acid & $0.40 \pm 0.12^{b}$ & $0.91 \pm 0.16{ }^{b}$ & $2.15 \pm 0.32^{b}$ \\
\hline Diabetic rats treated with epicatechin and gallic acid & $0.75 \pm 0.14^{b}$ & $1.11 \pm 0.05^{b}$ & $2.00 \pm 0.17^{b}$ \\
\hline
\end{tabular}

Super script a significant as compared with normal control.

- Super script b significant as compared with Diabetic control.

The homeostatic model assessment (HOMA) which is a method used to quantify insulin resistance and beta-cell function, as in table 2.

- Super script a significant as compared with normal.

- Super script b significant as compared with Diabetic control.

Effect of epicatechin and/or gallic acid on mediators

RT-PCR had been done for estimate the expression of genes Glut 4 (Glucose transporter type 4) and Resistin (insulin resistant) with Beta actin as a house keeping gene. There was difference between PCR products of normal control or diabetic control and diabetic groups
Table 2: the HOMA IR, HOMA IS and HOMA- $\beta$ cell function of diffrenet Groups of the NA/STZ-induced diabetic rats. treated with epicatechin and/or gallic acid as in table 3.

Table3: effect of epicatchin and/or gallic acid on resistin and Glucose transporter type 4 (GLUT4) According to Beta-actin ( $\beta$-actin) in STZ/NA - Induced Diabetic Rat 


\begin{tabular}{|c|c|c|}
\hline Normal & $85.21 \pm 6.39$ & $154.33 \pm 10.95$ \\
\hline Diabetic control & $117.54 \pm 18.67^{\mathrm{a}}$ & $100.61 \pm 3.24^{\mathrm{a}}$ \\
\hline Biabetic rats treated with epieateehin & CK-MB ${ }^{104}+14.7_{\text {LDH }}^{\mathrm{b}}$ & $105.952^{2} \cdot 9^{b}$ \\
\hline Diabetic rats treated with galikramidter & $(\mathrm{U} / \mathrm{L}) 1.02 \pm 8.8 \mathrm{~b}(\mathrm{U} / \mathrm{L})$ & $103.06 \pm\left(17.95^{b}\right.$ \\
\hline $\begin{array}{l}\text { Group } \\
\text { Diabetic rats treated with epicatechin and gallic acid }\end{array}$ & $86.74 \pm 11.68^{b}$ & $130.57 \pm 7.57^{b}$ \\
\hline
\end{tabular}

Super script a significant as compared with normal.

- Super script b significant as compared with Diabetic control.

Effect of epicatechin and/or gallic acid on lipid profile

The serum Total cholesterol, triglycerides, high density lipoprotein and low density lipoprotein. Elevated in NA-STZ diabetic rats as compared with normal rats, the treatment of diabetic rats with epicatechin and/or gallic acid produced a potential amelioration as decreased the total cholesterol, triglycerides, LDL, and increase the HDL levels as in Table 4.

Table 4: Serum lipid profile in normal, diabetic control and diabetic rats treated with epicatechin and/or gallic acid.

\begin{tabular}{|c|c|c|c|c|}
\hline Parameter & $\begin{array}{l}\text { Cholesterol } \\
\text { (mg/dl) }\end{array}$ & $\begin{array}{c}\text { Tri } \\
\text { glycerides } \\
\text { (mg/dl) }\end{array}$ & $\begin{array}{c}\text { HDL- } \\
\text { Cholesterol }\end{array}$ & $\begin{array}{c}\text { LDL- } \\
\text { Cholesterol }\end{array}$ \\
\hline Normal & $73.00 \pm 3.34$ & $44.00 \pm 5.43$ & $36.66 \pm 3.01$ & $33.53 \pm 0.58$ \\
\hline Diabetic control & $114.66 \pm 5.83^{a}$ & $87.50 \pm 5.43^{a}$ & $26.16 \pm 2.48^{a}$ & $71.00 \pm 2.75^{a}$ \\
\hline Diabetic rats treated with epicatechin & $93.66 \pm 5.392^{b}$ & $69.00 \pm 4.09^{b}$ & $30.83 \pm 3.18^{b}$ & $45.68 \pm 2.75^{b}$ \\
\hline Diabetic rats treated with gallic acid & $96.33 \pm 4.32^{b}$ & $73.66 \pm 5.35^{b}$ & $28.83 \pm 3.18^{b}$ & $48.68 \pm 1.19^{b}$ \\
\hline $\begin{array}{l}\text { Diabetic rats treated with epicatechin and } \\
\text { gallic acid }\end{array}$ & $84.16 \pm 3.00^{b}$ & $56.66 \pm 3.98^{b}$ & $32.33 \pm 4.222^{b}$ & $36.00 \pm 1.37^{b}$ \\
\hline
\end{tabular}

- Superscript a: significant as compared with normal.

- Superscript b: significant as compared with Diabetic control.

Effect of epicatechin and/or gallic acid on heart function indicators

Depict the effect of epicatechin and/or gallic acid administration on some cardiac function biomarkers in serum of diabetic rats. Serum CK-MB, AST and LDH activities were increased all in diabetic rats compared with normal one. However the treatment with epicatechin and/or gallic acid produces a significant decrease in all of these parameters compared with diabetic ones but we found that the treatment by a mixture of epicatechin and gallic acid seemed to be more effective and improve especially serum CK-MB and LDH than each alone.

Table5: effect of epicatchin and/or gallic acid on serum enzyme activities related to heart function in STZ/NA - Induced Diabetic Rats. 


\begin{tabular}{|c|c|c|c|}
\hline Normal control & 38.78 \pm 1.87 & $189.66 \pm 14.79$ & $34.66 \pm 3.07$ \\
\hline Diabetic control & $110.25 \pm 9.8^{\mathrm{a}}$ & $615.5 \pm 24.88^{a}$ & $68.66 \pm 4.63^{b}$ \\
\hline Diabetic rats treated with epicatechin & $85.83 \pm 5.19^{b}$ & $266.83 \pm 14.89^{b}$ & $54.33 \pm 3.66^{b}$ \\
\hline Diabetic rats treated with gallic acid & $90.51 \pm 5.08^{b}$ & $274.16 \pm 14.66^{b}$ & $59 \pm 2.6^{b}$ \\
\hline Diabetic rats treated with epicatechin and gallic acid & $53.5 \pm 6.18 \mathrm{~b}$ & $248.83 \pm 13.78^{b}$ & $47.16 \pm 5.9^{b}$ \\
\hline
\end{tabular}

- Superscript a: significant as compared with normal.

- Superscript b: significant as compared with Diabetic control.

\section{DISCUSSION}

Type 2 diabetes is typically a chronic disease associated with a ten-year-shorter life expectancy (Melmed et al., 2015). This is partly due to a number of complications with which it is associated, including: two to four times the risk of cardiovascular disease, including ischemic heart disease and stroke; a 20 -fold increase in lower limb amputations, and increased rates of hospitalizations. (Melmed et al., 2015). In the developed world, and increasingly elsewhere, type 2 diabetes is the largest cause nontraumatic blindness and kidney failure
(Ripsin et al., 2009). It has also been associated with an increased risk of cognitive dysfunction and dementia through disease processes such as Alzheimer's disease and vascular dementia (Pasquier et al., 2010) Other complications include acanthosis nigricans, sexual dysfunction, and frequent infections (Vijan, 2010).

Lifestyle factors are important to the development of type 2 diabetes, including obesity and being overweight (defined by a body mass index of greater than 25), lack of physical activity, poor diet, stress, and urbanization (Abdullah et al., 2010). Excess body fat is associated with 60 $80 \%$ of cases in those of European and African descent also among those who are not obese, a high waist-hip ratio is often present (Gardner $e t$ al., 2011). Smoking appears to increase the risk of type 2 diabetes mellitus (Pan et al., 2015).
Dietary factors also influence the risk of developing type 2 diabetes. Consumption of sugar-sweetened drinks in excess is associated with an increased risk (Malik, et al., 2010). The type of fats in the diet are important, with saturated fats and trans fatty acids increasing the risk, and polyunsaturated and monounsaturated fat decreasing the risk, eating a lot of white rice appears to play a role in increasing risk ( $\mathrm{Hu}$ et al., 2012). A lack of exercise is believed to cause $7 \%$ of cases, persistent organic pollutants may play a role (Jump et al., 2010).

The development of type 2 diabetes is caused by a combination of lifestyle and genetic factors while some of these factors are under personal control, such as diet and obesity, other factors are not, such as increasing age, female gender, and genetics (Melmed et al., 2015). A lack of sleep has been linked to type 2 diabetes this is believed to act through its effect on metabolism (Touma et al., 2011). The nutritional status of a mother during fetal development may also play a role, with one proposed mechanism being that of altered DNA methylation the intestinal bacteriæ Prevotella copri and Bacteroides vulgatus have been connected with type 2 diabetes (Pedersen et al., 2016).

Oral glucose tolerance test (OGTT) is a well assay for screening the antihyperglycemic activity of any hypoglycemic agent (Manish $e t$ al., 2016). In the diabetic animals, the present data indicate a marked increase in serum 
glucose levels as compared to normal rats but by the treatment with epicatechin or gallic acid or the two in combination produced a great hypoglycemic effect on rats espicilly treated with a mixture of epicatechin and gallic acid and these results agree with (Bahadoran et al., 2013; Ly et al., 2015; Marcela et al., 2016 and Yang et al., 2016). Glucose intolerance could arise from either a defect in insulin secretion as in case of insulin dependent diabetes mellitus or a defect in insulin resistance as in case of noninsulin dependent diabetes mellitus .Diabetogenic agents, like STZ, selectively destruct $\beta$-cells of the islets of Langerhans in the pancreas (Amin et al., 2016). Results in an inhibition of the insulin synthesis and elevation of blood glucose due to (a) a reduce entry of glucose to peripheral tissue, muscle and adipose tissue (Birbrair et al., 2013). (b) Increase glycogen break down (María et al., 2016) (c) increase gluconeogenesis and hepatic glucose production (RAFAEL et al., 2015).

Adminstration of STZ caused rapid destruction of pancreatic $\beta$-cells in rats, which led to impaired glucose stimulated insulin release and insulin resistance, both of which are marked feature of type II diabetes (Amin et al., 2016). In comparison with the normal control rats, the present study revealed a highly significant decrease in fasting (insulin and CPeptide levels) of NA/STZ diabetic rats. Serum insulin and C-Peptide concentrations was increased markedly as a result of treating diabetic rats with epicatechin or gallic acid and these results run parallel with Xiao et al. (2015), Hanhineva et al. (2010) and Yoona et al. (2016) and here in our study we found that the combination between epicatechin and gallic acid have the greatest effect. Thus it was hypothesized that the possible mechanism of epicatechin and gallic acid on hypoglycemic action may be through potentiation of pancreatic secreation of insulin and C-Peptide from $\beta$-cell of islets and / or enhanced transport of blood glucose to the peripheral tissue, or by another mechanism such as stimulation of glucose uptake by peripheral tissue, inhibition of endogenous glucose production or activation of gluconeogenesis in liver and muscle (Rui, 2014).

HOMA models a method that assesses $\beta$-cell function (HOMA- $\beta$ ), insulin sensitivity (HOMA IS) and insulin resistance (HOMA-IR) from basal glucose and insulin, or C-peptide, concentrations. HOMA is a member of a family of paradigmatic models which are physiological-based structural models with theoretical solutions adjusted to population norms. Thus, data from individuals can be used to yield estimates of $\beta$-cell function and insulin sensitivity from the solution of the model without further computation. HOMA is a model of the relationship between glucose and insulin dynamics that predicts fasting steady-state glucose and insulin concentrations for a wide range of possible combinations of IR and $\beta$-cell function. Insulin levels depend on the pancreatic $\beta$-cell effect on glucose concentrations, while glucose concentrations are regulated through insulin-mediated glucose production by the liver. Thus, deficient $\beta$-cell function will echo a diminished response of $\beta$ cell to glucose-stimulated insulin secretion similarly, IR is reflected in the diminished suppressive effect of insulin on hepatic glucose production. Therefore, HOMA describes this glucose-insulin homeostasis (Muniyappa et al., 2008) and complementing to the improved results of insulin and C-Peptide concentration we found also that by the treatment the $\beta$-cell function and insulin sensitivity increase gradually and the insulin resistance decreased these results are in agreement with Abdul et al, (2006), Song et al. (2014), Santana et al. (2015) and Chih et al. (2015). The mixture of epicatechin and gallic acid was the most potent in improving $\beta$-cell function.

As the transport of glucose into most mammalian cells occurs by facilitated diffusion, mediated by a family of glucose transporter protein (Zhao and Keating, 2007). Insulin sensitive tissue express GLUT4, which is responsible for the large increase in glucose uptake into skeletal muscle, cardiac muscle, and adipose tissue (Birgit et al., 2015). In diabetic state, adipocytes show a dramatic reduction in GLUT4 expression, which is due to repression 
at a pretranslational level, because GLUT4 mRNA levels are also very markedly reduced (Nathan et al., 2016).

Here our study found that the rate of adipose tissue GLUT4 mRNA was significantly decreased in NA/STZ diabetic rats when compared to normal ones and this agree with various puplications (Palsgaard, 2009; Kampmann, 2011; Ramachandran et al., 2015; Andreas et al., 2017). In which STZ-induced diabetes is characterized by a repressed transcription rate of GLUT4 gene in adipose tissue. Treatment with epicatechin as well as gallic acid induced a potential increase in GLUT4 mRNA expression which contributed to the glucose lowering mechanism of both tested agents. The increased GLUT4 expression may be due to insulin secretory and sensitizing effects of epicatechin and gallic acid also the bestiality still by treatment with the mixture of the two products.

Resistin possesses the characteristics of inflammation factors, such as inhibiting generation of adipose cells, enhancing resistance against insulin and regulating glycometabolism, which could finally lead to atherosclerosis (Codoner et al., 2015). Our study found that the resistin increased in diabetic rats and this in line with (Yacir et al., 2013; Chiara et al., 2016; Asimina et al., 2016) but after treatment with epicatechin and gallic acid decreased gradually and the most preferable results found by treatment with the combination of two products.

Regarding the antihyperlipidemic effect of insulin, it is well known that insulin activates the enzyme, lipoprotein lipase (LPL), which hydrolyzes triglyceride under normal conditions. Dysfunction of LPL in insulin deficient state contributes to hypertriglyceridemia due to impaired catabolism of triglyceride-rich particles (Daisaku et al., 2017). On other hand, insulin increases receptor mediated removal of LDLcholesterol and hence decrease activity of insulin during diabetes leads to increased level of serum LDL-cholesterol and consequently hypercholesterolemia (Irena et al., 2010; Sebastiano et al., 2011). The abnormally high concentration of serum lipids in DM is mainly due to an increase in the mobilization of FFAs from the peripheral fat depots, since insulin inhibits the hormone-sensitive lipase (HSL) (Emily et al., 2016). The marked hyperlipidemia that characterizes the diabetic state may. Therefore, be regarded as a consequence of the uninhibited actions of lipolytic hormones on fat depots. Excess of fatty acids in plasma produced by STZ promotes the liver conversion of some fatty acids to phospholipids and cholesterol. These two substances, along with excess of TG formed in the liver, may be discharged into lipoproteins in the blood. As a result, serum phospholipids are elevated (Yue Yuan et al., 2016).

In the current study, the rise in blood glucose was accompanied by a marked increase in total cholesterol (TC), low density lipoprotein cholesterol (LDL-C), triglycerides (TG) and reduction in hight density lipoprotein cholesterol (HDL-C) in NA/STZ diabetic rats these results (Puhong et al., 2016; Ben Hmad et al., 2016; Ntchapda et al., 2017). Here the treatments of NA/STZ diabetic rats with epicatechin and/or gallic acid produced a sensational improvement of altered serum lipid variables. These results agree with (Sauvik et al. (2013), Ya Ju et al. (2015), Zhao et al. (2014), Pal et al. (2012) and Razack et al. (2015).

In reference to the serum biochemical markers of cardiac function the present study revealed that serum CK-MB, AST, LDH enzyme activities were markedly increased in diabetic rats and this coincide with (Suanarunsawat et al., 2011; SUANARUNSAWAT et al., 2016). We also found that epicatechin and gallic acid reduces the risk of Myocardial infarction (MI) which is a common presentation of ischemic heart disease (IHD) and play an important role in the treatment of coronary artery diseases (CAD) (Khalil et al., 2015). CK-MB isoenzyme activity is useful as an index for the early diagnosis of not only myocardial infarction, but also any type of myocardial injury. Leakage of cytosolic enzymes including CK-MB, LDH, 
and AST into the blood stream may occur when cell membranes become more permeable or rupture (Khalil et al., 2015). The amounts of these cellular enzymes in the serum reflect the alterations in plasma membrane integrity and/or permeability. Furthermore, the amount of the enzymes appearing in serum is reported to be proportional to the number of necrotic cells, which also reflects a nonspecific alteration in the plasma membrane integrity and/or permeability as a response to $\beta$-adrenergic stimulation (APASL et al., 2008; Jason et al., 2016).

Pretreatment with epicatechin and/or gallic acid, however, resulted in lowered activities of all marker enzymes in the serum, indicating that epicatechin andlor gallic acid helps in maintaining the membrane integrity, thereby restricting the leakage of these

\section{REFERENCES}

Abdul-Ghani MA, Tripathy D, DeFronzo RA. Contributions of beta-cell dysfunction and insulin resistance to the pathogenesis of impaired glucose tolerance and impaired fasting glucose. Diabetes

care. 2006;29(5):1130-9. doi: $10.2337 / \mathrm{dc} 05-2179$.

Abdullah, A; Peeters, A; de Courten, M; Stoelwinder, J (September 2010). "The magnitude of association between overweight and obesity and the risk of diabetes: a meta-analysis of prospective cohort studies.". Diabetes research and clinical practice. 89 (3): 309-

19. doi:10.1016/j.diabres.2010.04.012

Amin Al-awar, Krisztina Kupai, Médea Veszelka, Gergő Szücs, Zouhair Attieh, Zsolt Murlasits, Szilvia Török, Anikó Pósa, and Csaba Varga J Diabetes Res. 2016; 2016: 9051426.Published online 2016 Aug 9. doi: 10.1155/2016/9051426. enzymes. Phenolic acids such as gallic acid and flavonoids such as catechin are important constitutive antioxidants as in our study.

\section{CONCLUSION}

Our results clearly indicate that both epicatechin and gallic acid, have hypoglycemic effects in NA/STZ-induced diabetic rats which may be mediated via potentiation of insulin secretion from $\beta$-cells resulting in better control of hypoglycemia and its related abnormalities; therefore, it can concluded that both compounds especially the mixture of epicatechin and gallic acid are potent hypoglycemic agents that can prevent the development of diabetic complications.

Andreas Buch Møller, Ulla Kampmann, Jakob Hedegaard, KasperThorsen,Iver Nordentoft, Mikkel Holm Vendelbo, Niels Møller and Niels Jessen.Altered gene expression and repressed markers of autophagy in skeletal muscle of insulin resistant patients with type 2 diabetes Scientific Reports 7, Article number: 43775 (2017). doi:10.1038/srep43775.

Anthony Campbell - MA PhD, Cardiff University, retrieved 29 December 2012.

APASL Seoul 2008 Meeting. Hepatology International. 2008;2 (Suppl 3):213552. doi:10.1007/s12072-008-91012.approach to screening and diagnosis of gestational diabetes. J Obstet Gynaecol. 2017 May 3:1-9. doi: 10.1080/01443615.2017.

1306692.approachto screening and diagnosis of gestational diabetes. J Obstet Gynaecol. 2017 May 3:1-9. doi: 10.1080/01443615.2017.1306

Asimina Kerimi, Gary Williamson. Mol Nutr Food Res. 2016 Aug; 60(8): 1770- 
1788. Published online 2016 Mar29. doi: 10.1002/mnfr.201500940 PMCID: PMC5021119.

Atanasov PK, Chan JC, Gagliardino JJ, Mbanya JC, Shestakova MV, LeguetDinville P, Annemans L.Value Health. 2015 Nov;18(7):A619. doi: 10.1016/j.jval.2015.09.2165.

Epub 2015 Oct 20. No abstract available. PMID: 26533476. Aug; 78(8):979-86.

Bahadoran Z., Mirmiran P., Azizi F. Dietary polyphenols as potential nutraceuticals in management of diabetes: a review. Journal of Diabetes and Metabolic Disorders. 2013;12, article 43 doi: 10.1186/2251-6581-1243.

Ben Hmad Halima, Khlifi Sarra, Ben Jemaa Houda, Gara Sonia and Aouidet Abdallah, 2016. Antihyperglycemic, Antihyperlipidemic and Modulatory Effects of Apple Cider Vinegar on Digestive Enzymes in Experimental Diabetic Rats. International Journal of Pharmacology, 12: 505-513.

Bing C, Gomez Ambrosi J, Zabalegui N, Williams G \& Trayhurn P 2002 Resistin and RELM-alpha gene expression in white adipose tissue of lactating mice. Biochemical and Biophysical Research Communications 296 458-462.

Birbrair, Alexander; Zhang, Tan; Wang, Zhong-Min; Messi, Maria Laura; Enikolopov, Grigori N.; Mintz, Akiva; Delbono, Osvaldo (2013-0321). "Role of Pericytes in Skeletal Muscle Regeneration and Fat Accumulation". Stem Cells and Development. 22 (16): 2298 2314. doi:

10.1089/scd.2012.0647. ISSN 15473287. PMC 3730538.

Birgit Gustafson, Shahram Hedjazifar, Silvia Gogg, Ann Hammarstedt, Ulf Smith Insulin resistance and impaired adipogenesis Volume 26, Issue 4,p193-
200,April2015DOI: http://dx.doi.org/1

0.1016/j.tem.2015. 01.006.

Bnouham M, Bendahou M, El Haouari M, Aziz M, Ziyyat A, Legssyer A, Mekhfi H.Inhibition of rat platelet aggregation by Urtica dioica leaves extracts.

Chiara Di Lorenzo, Enrico Sangiovanni, Marco Fumagalli, Elisa Colombo, Gianfranco Frigerio, Francesca Colombo, Luis Peres de Sousa, Ahmet Altindişli, Patrizia Restani, Mario Dell'AgliInt J Mol Sci. 2016 Jul; 17(7): 1156. Published online 2016 Jul

19. doi: 10.3390/ijms17071156PMCI D: PMC4964528.

Chih-Wei Chang, Yi-Ju Hsu, Yi-Ming Chen, Wen-Ching Huang, Chi-Chang Huang, and Mei-Chich HsuEffects of combined extract of cocoa, coffee, green tea and garcinia on lipid profiles, glycaemic markers and inflammatory responses in hamsters BMC Complement Altern Med. 2015; 15: 269.Published online 2015 Aug 12. doi: 10.1186/s12906-015-0806-1.

Codoner-Franch P, Alonso-Iglesias $\quad \mathrm{E}$ (2015). Resistin: insulin resistance to malignancy. Clin Chim Acta, 438: 4654.

Daisaku Masuda, Shizuya Yamashita.J Atheroscler Thromb. 2017 Feb 1; 24(2): 95-109. doi: 10.5551/jat. RV16003.PMCID: PMC5305681.

Ebers

papyrus.http://www.crystalinks.com/e gyptmedicine.html - ancient Egyptian medicine.

Emily C. Dunford and Michael C. Riddell* Metabolites. 2016 Dec; 6(4): 44.Published online 2016 Dec 5. doi: 10.3390/metabo6040044.

Fiolet JW, Willebrands AF, Lie KI, ter Welle HF.Clin Chim Acta. 1977 Oct 1;80(1):23-35.PMID:908145.

Forbes JM1, Cooper ME. Mechanisms of diabetic complications. Physiol 
Rev. 2013 Jan;93(1):137-88. doi: 10.1152/physrev.00045.2011.

Gardner, David G.; Shoback, Dolores, eds. (2011). "Chapter 17: Pancreatic hormones \& diabetes mellitus". Greenspan's basic \& clinical endocrinology (9th ed.). New York: McGraw-Hill Medical. ISBN 007-162243-8. OCLC 613429053.

Gella FJ, Olivella T, Cruz Pastor M, Arenas J, Moreno R, Durban R, Gómez JA. A simple procedure for routine determination of aspartate aminotransferase and alanine aminotransferase with pyridoxal phosphate. Clin Chim Acta,1985, 153: 241247.

Godinho R, Mega C, Teixeira-de-Lemos E, Carvalho E, Teixeira F, Fernandes R, Reis F.J Diabetes Res. 2015;2015:806979.doi:10.1155/2 015/806979. Epub 2015 May 17. Review.PMID:26075286.

Greenan, N. S., R.L. Mulvaney, and G.K. Sims. 1995. A microscale method for colorimetric determination of urea in soil extracts. Commun. Soil Sci. Plant Anal. 26:2519-2529.

Hanhineva K., Torronen R., Bondia-Pons I., Pekkinen J., Kolehmainen M., Mykkanen H., Poutanen K. Impact of dietary polyphenols on carbohydrate metabolism. Int. J. Mol. Sci. 2010;11:1365-1402. doi: 10.3390/ijms11041365.

Hanhineva K., Torronen R., Bondia-Pons I., Pekkinen J., Kolehmainen M., Mykkanen H., Poutanen K. Impact of dietary polyphenols on carbohydrate metabolism. Int. J. Mol. Sci. 2010;11:1365-1402. doi: 10.3390/ijms11041365.

Holmes RS, Goldberg E (Oct 2009). "Computational analyses of mammalian lactate dehydrogenases: human, mouse, opossum and platypus LDHs". Computational Biology and Chemistry. 33 (5): 379-85.
Hu, EA; Pan, A; Malik, V; Sun, Q (2012-0315). "White rice consumption and risk of type 2 diabetes: meta-analysis and systematic review". BMJ (Clinical research ed.). 344: e1454. doi:10.1136/bmj.e1454. PMC 3307808ə. PMID 22422870.

Irena Levitan, Suncica Volkov, Papasani V. Subbaiah.Antioxid Redox Signal. 2010 Jul 1; 13(1): 3975. doi: 10.1089/ars.2009.2733PMCI D:PMC2877120.

Islam MA, Alam F, Solayman M, Khalil MI, Kamal MA, Gan SH.Oxid Med Cell Longev. 2016;2016:5137431.

Epub 2016 Sep $\quad 19 . \quad$ Review. PMID:27721914.

Jason Kar Sheng Lew,1 James T. Pearson,2,3 Daryl O.

Schwenke, 囚1 and Rajesh Katare Cardiovasc Diabetol. 2017; 16: 10.Published online 2017 Jan 13. doi: 10.1186/s12933-016-0484-4.

Jump up^^ Lee, I-Min; Shiroma, Eric J; Lobelo, Felipe; Puska, Pekka; Blair, Steven N; Katzmarzyk, Peter T (1 July 2012). "Effect of physical inactivity on major non-communicable diseases worldwide: an analysis of burden of disease and life expectancy". The Lancet. 380 (9838): 21929. doi:10.1016/S01406736(12)61031-

9. PMC 3645500ة. PMID 22818936.

Kampmann, U. 1. GLUT4 and UBC9 protein expression is reduced in muscle from type 2 diabetic patients with severe insulin resistance. PLoS One 6, e27854 (2011).

Khalil MI, Ahmmed I, Ahmed R, et al. Amelioration of IsoproterenolInduced Oxidative Damage in Rat Myocardium somnifera Leaf

Research by Withania 2015;2015:624159. doi:10.1155/2015/624159.

Khan HY, Zubair H, Faisal M, Ullah MF, Farhan M, Sarkar FH, Ahmad A, Hadi 
SM.Mol

Nutr

Food

Res. 2014 Mar;58(3):437-46. doi:

10.1002/mnfr.201300417. Epub 2013

Oct 1.PMID:24123728.

Korczowski MM. Dietary control of diabetes: reality or myth? South Med J. 1985

Krauss RM, Siri PW. Metabolic abnormalities: triglyceride and lowdensity lipoprotein. Endocrinol Metab Clin North Am. 2004;33:405-15.

Latha RC, Daisy P. Insulin-secretagogue, antihyperlipidemic and other protective effects of gallic acid isolated from Terminalia bellerica Roxb. In streptozotocin-induced diabetic rats. Chem Biol Interact. 2011 Jan15;189(1-2):112-8. doi: 10.1016/j.cbi.2010.11.005. Epub 2010 Nov 13.

Leiter EH, Reifsnyder PC Differential levels of diabetogenic stress in two new mouse models of obesity and type 2 diabetes. Diabetes 53(Suppl 1): S4-11, 2004.

Liao CL, Lai KC, Huang AC, Yang JS, Lin JJ, Wu SH, Gibson Wood W, Lin JG, Chung JG. Gallic acid inhibits migration and invasion in human osteosarcoma U-2 OS cells through suppressing the matrix metalloproteinase-2/- 9, protein kinase $\mathrm{B}$ (PKB) and PKC signaling pathways. Food Chem Toxicol, 2012, 50: 1734-1740.

Ly C., Yockell-Lelièvre J., Ferraro Z. M., Arnason J. T., Ferrier J., Gruslin A. The effects of dietary polyphenols on reproductive health and early development. Human Reproduction Update. 2015;21(2):228-248. doi: 10.1093/humupd/dmu058.

Maiti R, Jana D, Das UK, Ghosh D (2004). Antidiabetic effect of aqueous extract of seed of Tamarindus indica in streptozotocininduced diabetic rats. J. Ethnopharmacol. 92: 85-91.

Malik, VS; Popkin, BM; Bray, GA; Després, JP; Willett, WC; Hu, FB (November 2010). "Sugar-Sweetened Beverages and Risk of Metabolic Syndrome and Type 2 Diabetes: A metaanalysis". Diabetes Care. 33 (11): 2477-83. doi:10.2337/dc101079. PMC 2963518. PMID 2069334 8.

Manach C, Williamson G, Morand C, Scalbert A, Rémésy C. Bioavailability and bioefficacy of polyphenols in humans:

I. Review of 97 bioavailability studies. Am J Clin Nutr, 2005, 81(1): 230S-42S.

Manish M. Wanjari,a, Sujata Mishra,

b Yadu Nandan Dey,a Deepti

Sharma,a Sudesh N.

Gaidhani,c and Ankush D. Jadhava Antidiabetic activity of Chandraprabha vati- A classical Ayurvedic formulation $\mathbf{J}$ Ayurveda Integr Med. 2016 Jul-Sep; 7(3): 144-150.Published online $2016 \quad$ Sep 22. doi: 10.1016/j.jaim.2016.08.010.

Mansouri MT, Farbood Y, Sameri MJ, Sarkaki A, Naghizadeh B, Rafeirad M. Neuroprotective effects of oral gallic acid against oxidative stress induced by 6-hydroxydopamine in rats. Food Chem, 2013, 138: 1028-1033.

Marcela Soto-García, 1 Martha RosalesCastro, 1 Gerardo N. EscalonaCardoso, 2 and Norma PaniaguaCastro 2 Evaluation of Hypoglycemic and Genotoxic Effect of Polyphenolic Bark Extract from Quercus sideroxylaEvid Based Complement Alternat Med. 2016; 2016: 4032618.Published online 2016 Oct 27. doi: $10.1155 / 2016 / 4032618$.

María M. Adeva-Andany, Manuel GonzálezLucán, Cristóbal DonapetryGarcía, Carlos Fernández-Fernández, and Eva Ameneiros-Rodríguez Glycogen metabolism in humans BBA Clin. 2016 Jun; 5: 85100.Published online 2016 Feb 27. doi: 10.1016/j.bbacli.2016.02.001

Masiello P, Broca C, Gross R, Roye 
M, Manteghetti M, Hillaire-Buys D, Novelli M, Ribes G. Experimental NIDDM: development of a new model in adult rats administered streptozotocin and nicotinamide. Diabetes. 1998 Feb;47(2):224-9.

Melmed, Shlomo; Polonsky, Kenneth S.; Larsen, P. Reed; Kronenberg, Henry M (2015). (eds.). Williams textbook of endocrinology. (12th ed.). Philadelphia: Elsevier/Saunders. pp. 1371-1435.

Muniyappa R, Lee S, Chen $\mathrm{H}$ et al. Current approaches for assessing insulin sensitivity and resistance in vivo: advantages, limitations, and appropriate usage. Am J Physiol Endocrinol Metab 2008; 294: E15E26.

Nathan L. Price,a,b Brandon Holtrup,c Stephanie L. Kwei,d Martin Wabitsch,e Matthew

Rodeheffer,c Laurence

Bianchini,f,g Yajaira

Suárez,a,b and Carlos FernándezHernando SREBP-1c/MicroRNA 33b Genomic Loci Control Adipocyte DifferentiationMol Cell Biol. 2016 Apr 1; 36(7): 1180-1193.Published online 2016 Mar 18. Prepublished online $2016 \quad$ Feb 1. doi: 10.1128/MCB.00745-15.

Ntchapda FidèleEmail author, Barama Joseph, Talla Emmanuel and Dimo Théophile BMC Complementary and Alternative MedicineBMC series - open, inclusive and trusted201717:76DOI: 10.1186/s1290 6-017-1566-x@ The Author(s). 2017.

Pal S, Saha C, Hossain M, Dey SK, Kumar GS. Influence of Galloyl Moiety in Interaction of Epicatechin with Bovine Serum Albumin: A Spectroscopic and Thermodynamic Characterization. Permyakov EA, ed. PLoS ONE. 2012;7(8):e43321. doi:10.1371/journal.pone.0043321.

Palsgaard, J. Gene expression in skeletal muscle biopsies from people with type
2 diabetes and relatives: differential regulation of insulin signaling pathways. PLoS One 4, e6575 (2009).

Pan, A; Wang, Y; Talaei, M; Hu, FB; Wu, T (17 September 2015). "Relation of active, passive, and quitting smoking with incident type 2 diabetes: a systematic review and metaanalysis.". The Lancet. Diabetes \& endocrinology. 3: 95867. doi:10.1016/S22138587(15)00316-2.

Pannala VR, (2010) Experimental and steadystate analysis of the GAL regulatory system in Kluyveromyces lactis. FEBS J 277(14):29873002 PMID:20528923.

Park T, Song SJ, Choi S. Decaffeinated green coffee bean extract attenuates dietinduced obesity and insulin resistance in mice. Evid-Based Compl Alt. 2014;2014:718379.

Pasquier, F (October 2010). "Diabetes and cognitive impairment: how to evaluate the cognitive status?". Diabetes \& metabolism. 36 Suppl 3: S1005. doi:10.1016/S1262-3636(10)704754.

Pedersen HK, Gudmundsdottir V, Nielsen HB, et al. (21 July 2016). "Human gut microbes impact host serum metabolome and insulin sensitivity". Nature. 535 (7612):37638 1. doi:10.1038/nature18646. PMID 27 409811. Phytother Res. 2006 Jul;20(7):568-72. proteins in oncogenic transformation. Cell Mol Biol (Noisy-le-grand). 2017 Jan 30;63(1):1-5. doi: $10.14715 / \mathrm{cmb} / 2017.63 .1 .1$.

Puhong Zhang, Jialin Gao, Chun Pu, Gang Feng, Lizhuo Wang, Lizhu Huang, Qingsong Tao, and Yao Zhang Lipids Health Dis. 2016; 15: 158.Published online $2016 \quad$ Sep 15. doi: 10.1186/s12944-016-0325-1. Raederstorff DG, Schlachter MF, Elste V, Weber P. Effect of EGCG on lipid absorption and plasma lipid levels in 
rats. J Nutr Biochem. 2003; 14:326-

332. doi: 10.1016/S09552863(03)00054-8.

RAFAEL O. ALVIM, MARCEL R. CHEUHEN, SILMARA

R. MACHADO, ANDRÉ GUSTAVO

P. SOUSA,

PAULO

C.J.L. SANTOS, General aspects of muscle glucose uptakeAn. Acad. Bras.

Ciênc. vol.87 no.1 Rio de

Janeiro Mar. $2015 \quad$ Epub Mar 06,

2015 http://dx.doi.org/10.1590/0001-

3765201520140225.

Ramachandran Vinayagam and Baojun $\mathrm{Xu}$ Antidiabetic properties of dietary flavonoids: a cellular mechanism review Nutr Metab (Lond). 2015; 12: 60.Published online 2015 Dec 23. doi: 10.1186/s12986-015-0057-7.

Razack S, Hemanth Kumar K, Nallamuthu I, Naika M, Khanum F. Antioxidant, Biomolecule Oxidation Protective Activities of Nardostachys jatamansi DC and Its Phytochemical Analysis by RP-HPLC and GC-MS. Segura-Carretero A, Arráez-Román D, eds. Antioxidants. 2015;4(1):185203. doi:10.3390/antiox4010185.

Reckziegel P, Dias VT, Benvegnu' D, Boufleur N, Silva Barcelos RC, Segat HJ, Pase CS, Dos Santos CM, Flores EM, $\mathrm{Bu}$ "rger ME. Locomotor damage and brain oxidative stress induced by lead exposure are attenuated by gallic acid treatment. Toxicol Lett, 2011, 203: 74-81.

Ripsin CM, Kang H, Urban RJ (January 2009). "Management of blood glucose in type 2 diabetes mellitus". Am Fam Physician. 79 (1): 29-36.

Roy CK, Ojha JK, Bajpai HS. A review of the history of prameha and diabetes

Royal College of General Practitioners. NHS Diabetes. Coding, classification and diagnosis of diabetes. A review of the coding, classification and diagnosis of diabetes in primary care in England with recommendations for improvement. 2011. http://www.sdrn.org.uk/sites/sdrn.org. uk/files/nhs \%20diagnosis $\% 20$ classification\%20report.pdf (accessed 14 Mar 2016).

Rui L. Energy Metabolism in the Liver. Comprehensive Physiology. 2014;4(1):177-197. doi:10.1002/cphy.c130024.

Santana A, Santamarina A, Souza G, Mennitti L, Okuda M, Venancio $\mathrm{D}$ et al. Decaffeinated green tea extract rich in epigallocatechin-3-gallate improves insulin resistance and metabolic profiles in normolipidic diet-but not high-fat diet-fed mice. J Nutr Biochem. 2015. doi:10.1016/j.jnutbio.2015.03.001.

Sauvik Bhattacharyya, Sk Milan Ahammed, Bishnu Pada Saha, Pulok K. MukherjeeAAPS

PharmSciTech. $2013 \quad$ Sep; 14(3): 1025-1033. Published online 2013 Jun 26. doi: 10.1208/s12249-0139991-8.PMCID:PMC3755146.

Sebastiano Calandra, Patrizia Tarugi, Helen E. Speedy, Andrew F. Dean, Stefano Bertolini, Carol C. ShouldersJ Lipid Res. $2011 \quad$ Nov; 52(11): 18851926. doi: 10.1194/jlr.R017855.

Shaker O, Sourour DA. How to

Protect doxorubicin-induced cardiomyopathy

in male albino rats? $\mathrm{J}$ Cardiovasc Pharmacol. 2010 Mar; 55(3):262-8. doi:10.1097/FJC.0b013e3181cf91ac.

PubMed PMID: 20051877.

Song SJ, Choi S, Park T. Decaffeinated green coffee bean extract attenuates dietinduced obesity and insulin resistance in mice. Evid-Based Compl Alt. 2014;2014:718379.

Suanarunsawat T, Devakul Na Ayutthaya W, Songsak T, Thirawarapan S, Poungshompoo S. Lipid-Lowering and Antioxidative Activities of Aqueous Extracts of Ocimum sanctum L. Leaves in Rats Fed with a High-Cholesterol Diet. Oxidative 
Medicine and Cellular

Longevity.2011;2011:962025.

doi:10.1155/2011/962025.

Tokushi Komatsu, Fumiaki Itoh, Satoshi Mikawa and Koichi Hodate. Gene expression of resistin in adipose tissue Journal of Endocrinology (2003) 178, R1-R5 0022-0795/03/0178-R1.

Touma, C; Pannain, S (August 2011). "Does lack of sleep cause diabetes?". Cleveland Clinic journal of medicine. 78 (8): $\quad 549$ 58. doi:10.3949/ccjm. 78a.10165. PMID 21807927.

Vijan, S (2010-03-02). "Type 2 diabetes". Annals of Internal Medicine. 152 (5): ITC31-15; quiz ITC316. Doi:10.7326/0003-4819152-5-201003020-01003

Williamson G, Manach C. Bioavailability and bioefficacy of polyphenols in humans. II. Review of 93 intervention studies. Am J Clin Nutr. 2005 Jan; 81(1 Suppl):243S-255S.

Wu Y, Wang F, Fu M, Wang C, QuonMJ, YangP. Diabetes. $2015 \mathrm{Jul}$; 64(7):2526-36.doi: $\quad$ 10.2337/db141683.Epub $2015 \quad$ Feb 26.PMID:25720389.

Xiao J.B., Hogger P. Dietary polyphenols and type 2 diabetes: Current insights and future perspectives. Curr. Med. Chem. 2015;22:23-38. doi: $10.2174 / 09298673216661407061308$ 07.

Ya Ju Chang, Shih Lan Hsu, Yi Ting Liu, Yu Hsuan Lin, Ming Hui Lin, Shu Jung Huang, Ja-an Annie Ho, Li-Chen WuPLoS

One. 2015; 10(3): e0120713. Published online 2015 Mar 27. doi:

10.1371/journal.pone.0120713.PMCI D:PMC4376672.

Yacir Benomar, Arieh Gertler, Pamela De Lacy, Delphine Crépin, Hassina Ould Hamouda, Laure Riffault, Mohammed Taouis. Diabetes. 2013 Jan; 62(1): 102-114. Published online 2012 Dec 13. doi: 10.2337/ db12-0237PMCID: PMC 3526022.

Yang X., Kong F. Effects of tea polyphenols and different teas on pancreatic $\alpha$ amylase activity in vitro. LWT-Food Science and Technology. 2016;66:232-238. doi: 10.1016/j.lwt.2015.10.035.

Yoona Kim, Jennifer B. Keogh, and Peter M. CliftonPolyphenols and Glycemic Control Nutrients. 2016 Jan; 8(1): 17.Published online 2016 Jan 5. doi: 10.3390/nu8010017.

Yue Yuan,Jian Wen, Jie Tang, Qiming Kan,Rose Ackermann, Kar Olsen, and Anna SchwendemanInt J Nanomedicine. 2016; 11: 6229_ 6238.Published online 2016 Nov 22. doi: $10.2147 /$ IJN.S112835.

Zhao C, Li C, Liu S, Yang L. The Galloyl Catechins Contributing to Main Antioxidant Capacity of Tea Made from Camellia sinensis in China. The Scientific World Journal. 2014:2014:863984. doi:10.1155/2014/863984.

Zhao F-Q, Keating AF, Functional properties and genomics of glucose transporters. Current Genomics, 2007; 113-128. 